\title{
Pemberdayaan masyarakat melalui pengembangan desa mandiri energi (Studi kasus di Klaten Jawa Tengah)
}

\author{
Universitas Sebelas Maret \\ * ditawahyuningtyas@student.uns.ac.id
}

Dita Wahyu Ningtyas T. *, Suwarto, \& Eny Lestari

\begin{abstract}
Abstrak. Kegiatan ini bertujuan untuk mengkaji implementasi proses dan impact pemberdayaan masyarakat dalam pengembangan desa mandiri energi biogas di Desa Mundu Kecamatan Tulung Kabupaten Klaten. Kegiatan ini menunjukkan bahwa pemberdayaan masyarakat di Desa Mundu Kecamatan Tulung Kabupaten Klaten telah berlangsung sejak tahun 2014. Hingga saat ini sudah terdapat 40 instalasi digester yang terpasang. Pemberdayaan dilakukan dengan bantuan pendamping lapang LSM LPTP, hingga saat ini telah mendapatkan beberapa penghargaan. Tahapan pemberdayaan yang dilakukan dengan penyadaran, pengkapasitasan dan pemberian daya. Penyadaran dilakukan dengan menyadarkan akan potensi yang dimiliki oleh desa yaitu limbah kotoran ternak dan menanggulangi masalah polusi udara yang ditimbulkan dari limbah ternak. Pengkapasitasan dilakukan dengan memberikan pengkapasitasan pada manusia, organisasi dan system nilai, memberikan bimbingan berupa kegiatan pelatihan. Pemberian kepercayaan dilakukan dengan memberikan wewenang penuh masyarakat untuk mengelola biogas. Impact pemberdayaan ini adanya perubahan pola pikir, pola kerja, system nilai dan system usaha.
\end{abstract}

Kata Kunci : biogas, desa mandiri energi, pemberdayaan masyarakat.

\begin{abstract}
This study aims to examine the implementation of the process and impact of community empowerment in the development of an independent village of biogas energy in Mundu Village, Tulung District, Klaten Regency. The results showed that community empowerment in Mundu Village, Tulung District, Klaten Regency has been going on since 2014. Until now, there have been 40 more digester installations installed. Empowerment is carried out with the help of NGO field facilitators and has received several awards. The stages of empowerment are carried out by raising awareness, capacitating and empowering them. Awareness is carried out by making the village aware of the potential of livestock manure waste and overcoming the problem of air pollution caused by slag waste. Capacitating is carried out by providing capacitance to humans (individuals), organizations and value systems, providing guidance in the form of training activities. Trust is given by giving the community full authority to manage biogas. The impact of this empowerment is a change in mindset, work patterns, value systems and business systems.
\end{abstract}

Keywords: biogas, energy independent village, community empowerment

To cite this article: Ningtyas T, D. W., Suwarto, \& E. Lestari. 2020. Pemberdayaan masyarakat melalui pengembangan desa mandiri energi (Studi kasus di Klaten Jawa Tengah). Unri Conference Series: Community Engagement 2: 201-206. https://doi.org/10.31258/unricsce.2.201-206

(C) 2020 Authors

Peer-review under responsibility of the organizing committee of Seminar Nasional Pemberdayaan Masyarakat 2020 


\section{PENDAHULUAN}

Energi menjadi salah satu pilar penting dalam menggerakkan roda perekonomian. Tanpa adanya energi yang tercukupi bisa menghambat jalannya sector di bidang lain. Namun kondisi cadangan energi fosil saat ini sudah sangat menipis. Pengembangan energi terbarukan menjadi sebuah terobosan dalam menjaga kesetabilan energi. Disebutkan dalam Undang-Undang tentang Energi Nomor 30 Tahun 2007, sumber energi terbarukan apabila diolah dengan baik maka pemanfaatannya dapat berkelanjutan. Salah satu energi terbarukan yang berpotensi untuk dikembangkan adalah limbah kotoran ternak diolah menjadi biogas.

Pemanfaatan biogas menjadi salah satu upaya dalam mewujudkan swasembada energi desa untuk memenuhi kebutuhan energinya sendiri. Biogas menjadi salah satu energi alternatif yang bisa digunakan untuk bahan bakar yang ramah lingkungan. Energi terbarukan ini termasuk murah, gampang, serta bisa menjangkau sampai pelosok desa. Biogas bisa berasal dari kotoran manusia, kotoran hewan, sisa limbah rumah tangga, dan sampah biodegradable dalam keadaan anaerobik. Beberapa keuntungan penerapan biogas bagi masyarakat pedesaan adalah dapat digunakan untuk memasak, penerangan, pemompaan air dan variasi energi lainnya. Selain itu, memiliki manfaat yang tidak berwujud bagi masyarakat, seperti peningkatan kualitas lingkungan, kualitas pemeliharaan kesehatan dan standar hidup (Purohit \& Kandpal, 2007). Penggunaan kotoran sapi menjadi energi biogas mampu menurunkan emisi GRK dan berkontribusi meminimalkan dampak global pemanasan. Komponen utama biogas adalah metana $\left(\mathrm{CH}_{4}\right)$ dan karbon dioksida $\left(\mathrm{CO}_{2}\right)$ yang berkontribusi secara global pemanasan dan perubahan iklim (Listyawati et al., 2014).

Sebagai upaya menciptakan ketahanan energi, upaya pendekatan yang dilakukan melalui pengembangan Desa Mandiri Energi (DME). Bersumber pada Peraturan Menteri Energi dan Sumber Daya Mineral (ESDM) No 32 Tahun 2008 tentang Penyediaan, Pemanfaatan serta Tata Niaga Bahan Bakar Nabati (Biofuel), DME merupakan sebuah konsep desa yang bisa memproduksikan energi terbarukan serta mampu memenuhi kebutuhan energi minimum 60\% untuk kebutuhan desa. DME memiliki tujuan membangun kegiatan ekonomi produktif, menambah lapangan pekerjaan dan mengurangi kemiskinan untuk mensubstitusi bahan bakar minyak demi mewujudkan ketahanan daerah (Qadi et al., 2018).

Salah satu upaya untuk mengembangkan Desa Mandiri Energi dilakukan dengan pendekatan pemberdayaan masyarakat. Aspek pemberdayaan masyarakat merupakan usaha meningkatkan kemampuan dan kapasitas masyarakat supaya dapat memanfaatkan sumber daya yang tersedia untuk meningkatkan kesejahteraan, martabat, dan keberdayaan (Nasdian FR, 2006). Pemberdayaan masyarakat dilakukan melalui peningkatan kapasitasnya, sehingga mampu mengendalikan kehidupan mereka sendiri dengan melakukan pengelolaan terhadap sumber dayanya (Purwowibowo, Kris Hendrijanto, 2018). Proses pemberdayaan cenderung identik dengan faktor pendorong dalam aktivitas sosial ekonomi serta politik. Sebagaimana sudah disebutkan jika pemberdayaan ialah suatu upaya dan proses pengembangan diri untuk menggapai tujuan kemandirian. Wihatnolo, RR \& Dwidjowijoto (2007) mengemukakan pemberdayaan adalah "proses menjadi” bukan" proses praktis". Sebagaimana suatu proses tentu akan dihadapkan pada beberapa tahapan yaitu penyadaran, pengkapasitasan, serta pendayaan. 1) Penyadaran, tahapan ini memberikan pencerahan dalam wujud penyadaran bahwa mereka memiliki hak untuk memiliki suatu. Aktivitas yang menunjang tahapan ini seperti membagikan pengetahuan yang bersifat kognisi, beliefe serta healing. 2) Pengkapasitasan, tahapan ini meliputi tiga kegiatan antara lain pengkapasitasan manusia, pengkapasitasan organisasi dan pengkapasitasan system. 3) Penyadaran, tahapan ini masyarakat diberikan daya, kekuasaan, otoritas ataupun kesempatan sesuai keahlian yang dipunyai. Keahlian ini dinilai dari proses penyadaran serta pengkapasitasan yang sudah dijalankan. Pemberdayaan masyarakat desa memiliki tujuan untuk meningkatkan keahlian masyarakat sebagai upaya mengurangi intervensi pemerintah dan memberikan kewenangan dalam pengembangan wilayahnya. Sebagai upaya dalam memampukan dan memandirikan kehidupan masyarakat.

Desa Mundu Kecamatan Tulung Kabupaten Klaten merupakan salah satu desa yang telah mengembangkan program Desa Mandiri Energi Berbasis Biogas di wilayah Kecamatan Tulung, Kabupaten Klaten, Jawa Tengah. Desa Mundu telah memanfaatkan kotoran sapi menjadi energi biogas sejak 2014 kemudian berkolaborasi dengan pihak pemerintah dan pihak swasta dalam berbagai bentuk pelatihan dan pendampingan. Desa ini juga telah memperoleh beberapa penghargaan. Penelitian ini bertujuan untuk mengkaji proses pemberdayaan masyarakat dan impact pemberdayaan di Desa Mundu Kecamatan Tulung Kabupaten Klaten melalui pengembangan desa mandiri energi. 


\section{METODE PENERAPAN}

Lokasi kegiatan Pemberdayaan Masyarakat Melalui Pengembangan Desa Mandiri Energi di Desa Mundu Kecamatan Tulung Kabupaten Klaten. Pemilihan lokasi kegiatan dilakukan secara sengaja (purposive) karena Desa ini telah dan sedang mengembangkan desa mandiri energi bermula dari inisiatif dari warga masyarakat yang kemudian mendapatkan dukungan dari beberapa pihak. Desa Mundu jug a telah memperoleh beberapa penghargaan. Kecamatan Tulung ini mempunyai potensi yang besar akan renewable energi yaitu ternak sapi dan hasil kotoran ternak dari sapi perah. Walaupun lokasinya jauh dari pusat kota, namun kecamatan Tulung ini masih bisa diakses dengan infrastruktur jalan yang sudah baik. Ditambah lagi dengan adanya inisiatif dan semangat dari kelompok peternak di Desa Mundu Kecamatan Tulung untuk mengolah kotoran ternak menjadi biogas yang kemudian menjadi cikal bakal munculnya Desa Mandiri Energi di Kecamatan Tulung.

\section{HASIL DAN KETERCAPAIAN}

\section{Perkembangan pelaksanaan desa mandiri energi di Desa Mundu}

Kecamatan tulung merupakan sebuah kecamatan yang terletak di wilayah utara kabupaten Klaten dan berbatasan dengan Kabupaten Boyolali. Berjarak $15 \mathrm{~km}$ dari kabupaten Klaten. Secara geografis kecamatan Tulung ini terbagi menjadi dua wilayah yaitu barat dan timur. Wilayah barat masuk dalam daerah pegunungan menuju gunung Merapi sehingga mata pencaharian mayoritas masyarakat sebagai petani palawija dan peternak. Desa Mundu juga termasuk di dalam wilayah barat, mempunyai luas wilayah desa 236,77 Ha dengan sebagian besar lahan berupa ladang, kebun dan tegal seluas 136,18 ha. Jenis tanaman palawija yang ditanam di desa Mundu yaitu jagung dan ubi kayu. Banyak juga ditemui tanaman kolonjono yang menjadi pakan ternak. Selain memiliki potensi pertanian palawija di Desa Mundu juga mempunyai potensi peternakan. Berdasarkan hasil sensus yang dilakukan BPS Kabupaten Klaten tahun 2018 menyebutkan jumlah sapi terbanyak di Kecamatan Tulung yaitu sebanyak 8.266 ekor sapi. Hal ini didukung juga dengan kondisi wilayah geografis Mundu yang cocok untuk peternakan. Banyak tersedia makanan bagi ternak yang dapat dimanfaatkan untuk pakan.

Hewan ternak sapi yang dipelihari oleh masyarakat desa Mundu sebagian besar adalah sapi perah. Sebagaimana kita ketahui bahwa sapi menghasilkan kotoran ternak. Kotoran ternak ini yang kemudian dimanfaatkan oleh masyarakat di Desa Mundu menjadi biogas. Biogas ini bermula dari dulu pernah ada sosialisasi tentang pembuatan biogas namanya Program Biru yang dilaksanakan oleh Yayasan rumah energi bekerjasama dengan Kementrian Energi dan Sumber Daya Mineral. Namun saat itu tidak ada respon positif dari masyarakat. Kemudian di awal tahun 2014 masuk sosialisasi tentang biogas yang dilakukan oleh LPTP. Pada kegiatan yang didampingi oleh LPTP ini menghasilkan 1 reaktor biogas percontohan. Menurut penuturan dari Bapak Teguh selaku ketua kelompok ternak Margo Mulyo, antusia masyarakat mulai ada terhadap biogas semenjak ada pendampingan aktif dari LPTP. Bermula dari sosialisasi yang dilakukan oleh LPTP bersama pihak PT Tirta Investama Klaten, perangkat desa dan kelompok, semangat masyarakat mulai muncul dan mulai berinisiatif untuk membuat Arisan Biogas pada tahun 2014. Awal mulanya dari kelompok yang ikut serta dalam arisan ini dengan mengumpulkan uang senilai Rp. 500.000 kemudian bergotong royong dalam pembuatan demplot digester biogas. Waktu yang diperlukan dalam pengerjaan pembuatan demplot digester sampai pemasangan instalasinya membutuhkan waktu 1 minggu.

Beberapa penghargaan yang telah didapatkan antara lain, bulan Juni 2019 mendapatkan penghargaan dari lembaga Pengembangan Teknologi Pedesaan LPTP Award sebagai Desa mandiri energi biogas. Tahun 2018 memperoleh penghargaan juara 3 Desa Mandiri Energi tingkat Provinsi Jawa Tengah. Memperoleh penghargaan dari ISDA (Indonesian Suatainable Development Goals Awards) tahun 2018 kepada PT Tirta Investama Klaten, atas Programnya yang berjudul Inisiatif Kampung Mandiri Energi melalui Intervensi Teknologi Biogas di Desa Mundu. Penghargaan dari Kementerian Koordinator Bidang Pembangunan Manusia Dan Kebudayaan Republik Indonesia Tahun 2014 kepada PT Tirta Investama Klaten, atas programnya yang berjudul Pengembangan Biogas berbasis Masyarakat (Sistem Arisan Biogas) Di Desa Mundu Kecamatan Tulung. Hingga saat ini Desa Mundu sudah memiliki 40 reaktor pengolahan biogas aktif yang digunakan oleh perorangan maupun kolektif untuk memenuhi kebutuhan rumah tangga yaitu memasak.

\section{Proses kegiatan pemberdayaan masyarakat}

Proses kegiatan pemberdayaan masyarakat di Desa Mundu Kecamatan Tulung Kabupaten Klaten meliputi tiga tahapan yaitu penyadaran, pengkapasitasan dan pendayaan. 


\section{a. Penyadaran}

Proses pemberdayaan dari Masyarakat Desa Mundu berawal dari permasalahan limbah ternak yang banyak dan menyebabkan polusi udara. Melihat potensi yang dimiliki oleh desa yaitu jumlah ternak sapi yang banyak dan limbah kotoran ternak yang belum dimanfaatkan. Berangkat dari masyarakat yang masih tradisional yang sebagian besar mempunyai mata pencaharian sebagai petani sekaligus peternak, masyarakat Desa Mundu didampingi oleh LSM LPTP bersama-sama mengelola pengembangan Desa Mandiri Energi. Desa yang memiliki nilai tambah dan dapat memenuhi kebutuhan energi rumah tangga sendiri.

Pada awalnya LSM LPTP menberikan sosialisasi berupa wawasan dan pengetahuan tentang pentingnya biogas dan manfaat yang didapatkan dari penggunaan biogas. Hal ini menjadi usaha pencerahan yang dilakukan pada pertemuan yang rutin dilakukan. Secara perlahan masyarakat mulai sadar akan manfaat dan keuntungan penggunaan biogas. Biogas di desa Mundu dimanfaatkan sebagai bahan bakar untuk memasak. Hal ini menguntungkan dari segi ekonomi yaitu menghemat pengeluran untuk pembelian LPG setiap bulannya.

Proses pemberdayaan yang terjadi di Desa Mundu, pada tahapan penyadaran masyarakat memunculkan efek positif terhadap perubahan pengetahuan dan wawasan masyarakat. Munculnya motivasi masyarakat tentang manfaat biogas memberikan efek semangat dalam pengelolaan Desa Mandiri Energi. Masyarakat mulai sadar akan potensi yang dimiliki oleh desanya yang dapat dikembangkan dalam upaya meningkatkan kesejahteraan masyarakat. Penyadaran merupakan upaya membuka wawasan masyarakat sehinga mereka sadar untuk memajukan desanya sesuai dengan potensi yang dimiliki. Kemajuan menuju ke arah yang lebih baik dari sebelumnya, yaitu dengan meningkatkan taraf kehidupannya (Destiningrum et al., 2018). Proses pemberdayaan masyarakat yang terjadi di Desa Mundu mengikutsertakan masyarakat secara langsung dalam kegiatan perencanaan, pelaksanan dan evaluasi kegiatan.

\section{b. Pengkapasitasan}

Pengertian pengkapasitasan adalah penguatan kemampuan yang dimiliki oleh masyarakat. Peningkatan kapasitas sebagai sasaran dari kegiatan pemberdayaan masyarakat. Pengkapasitasan dalam pemberdayaan masyarakat sebagai upaya enabling atau memampukan. Mayarakat mampu terlebih dahulu sebelum diberikan daya atau kuasa. Pengkapasitasan dilakukan dengan memberikan pelatihan atau ketrampilan kepada masyarakat agar mahir (Skillfull) dalam mengelola sesuatu (Destiningrum et al., 2018).

Pemberdayaan masyarakat di Desa Mundu di bawah bimbingan LSM LPTP melakukan kegiatan pelatihan dan pendampingan. Awal mula LSM LPTP memberikan pencerahan tentang pertanian yaitu pemanfaatan lahan pekarangan untuk kegiatan pertanian. Seiring berjalannya waktu LPTP bersama masyarakat mulai focus kepada manajemen ternak mulai dari manajemen kandang sapi sampai hasil panen dan pengolahan biogas. Pelatihan pengelolaan biogas diawali dengan proyek digester percontohan dibuat masyarakat bersama LPTP. Digester percontohan ini pemasangan instalasi biogas dipandu dari tenaga ahli dari LPTP, masyarakat ikut mempelajari tata cara dalam pemasangannya. Berjalannya waktu muncul seorang tenaga ahli biogas dari Desa Mundu yaitu Pak Pono. Beliau sudah mendapatkan sertifikat tenaga ahli biogas, pernah membuat instalasi biogas sampai ke luar jawa.

Menurut penuturan Bapak Teguh (Ketua Kelompok Ternak) kelompok ternak pernah beberapa kali mendapatkan pelatihan dan bantuan yaitu dari LSM IDEA yaitu LSM dari Newzeland yang memberikan sosialisasi dan pelatihan tentang cara perawatan dan manajemen sapi perah. Mendapatkan bantuan sapi untuk kelompok peternak dua kali di tahun 2016 mendapatkan 12 ekor sapi dan tahun 2018 mendapatkan 15 ekor dari Dinas Provinsi Jawa Tengah. Beberapa kali mendapatkan pelatihan dari Dinas Peternakan Provinsi, tentang manajemen dan perawatan sapi, palatihan pasca panen susu yang diikuti oleh Bapak Teguh di Ungaran. Setelah dari pelatihan di ungaran itu, Bapak Teguh sebagai ketua kelompok peternak menginisiasi pembentukan Kelompok Wanita Tani (KWT) yang diikuti oleh para istri kelompok peternak. KWT ini yang mengolah susu menjadi olahan lainnya. Hasil olahan yang sudah dihasilkan antara lain sabun, permen, kerupuk, es krim dan yoguth. Mendapatkan bantuan peralatan dan pelatihan dari Dinas Peternakan Provinsi. Hasil dari olahan susu sapi ini masih aktif dijalankan oleh kelompok wanita tani (KWT). Namun terdapat kendala dalam pemasaran yang belum terlalu lancar.

Kegiatan pengkapasitasan meliputi pengkapasitasan manusia, organisasi dan system. Pengkapasitasan manusia dilakukan dalam bentuk pelatihan manajemen kendang sapi, mulai dari menjaga kebersihan kendang dan hewan ternak yang diadakan oleh LPTP dan LSM IDEA New Zealand. Pelatihan pengolahan limbah ternak menjadi biogas dan pupuk slury diadakan oleh LPTP. Pelatihan pembuatan pakan ternak dan Pelatihan pengolahan hasil susu menjadi produk makanan olahan diadakan oleh Pemerintah Provinsi Jawa Tengah. Pelatihan menjadi pemandu wisata diadakan oleh LPTP. 
Kegiatan pengkapasitasan dilakukan untuk meningkatkan ketrampilan dan pengetahuan individu atau kelompok yang diharapkan mampu mendukung proses perkembangan Desa Mandiri Energi. Selain itu juga untuk menunjang sustainability sehingga potensi yang dimiliki menghasilkan nilai tambah. Perlunya pengkapasitasan tentang produk olahan peternakan adalah sebagai upaya untuk meningkatkan pengetahuan masyarakat terhadap peluang usaha produk olahan.

Pengkapasitasan organisasi dilaksanakan dengan melakukan peningkatan kapasitas kelompok. Memberikan pembekalan tentang manajemen organisasi dan penguatan kelompok. Peningkatan kapasitas kelompok ini menjadikan lebih sinergis dalam setiap kegiatan dan berdampak positif pada perkembangan kelompok. Pengkapasitasan sistem nilai yaitu dalam bentuk kesepakatan bersama anggota kelompok dalam pengambilan keputusan. Hal ini akan membuat kelompok tetap bersatu karena keputusan yang diambil berdasarkan musyawarah bersama. Masyarakat dan kelompok peternak diberikan bekal pengetahuan dan keterampilan melalui sosialisasi dan pelatihan supaya keduanya memiliki keahlian untuk mengelola instalasi biogas (Aisah \& Herdiansyah, 2020). Pemberdayaan masyarakat dilakukan melalui peningkatan kapasitas sehingga mampu mengarahkan kehidupan mereka melalui pengelolaan sumber daya yang dimiliki (Purwowibowo, Kris Hendrijanto, 2018).

\section{c. Pemberian daya}

Pemberian daya dalam pemberdayaan dengan diberikannya ijin pengelolaan dan kepemilikan biogas secara mandiri. Kemudian bantuan berupa peralatan dan hewan sapi juga diberikan sepenuhnya ke kelompok. Kelompok diberi kepercayaan untuk mengelolanya. Harapannya kelompok mampu berjalan sendiri dalam mengembangkan potensinya. Pendayaan bagi anggota adalah memberikan kewenangan kepada anggota untuk membuka usaha dan mengelolanya secara mandiri, kewenangan ini diperlukan agar anggota memiliki kemandirian dalam bekerja dan berusaha (Destiningrum et al., 2018).

Pendayaan dilakukan dengan memberikan kekuatan atau kekuasaan penuh kepada sasaran. Pada pendayaan ini masyarakat mendapatkan kesempatan mengelola (merancang dan melaksanakan) setiap kegiatan. Prinsip ini sejalan dengan konsep keberdayaan masyarakat yang dikemukakan oleh Widjajanti (2011) keberdayaan masyarakat merupakan dimilikinya daya, kekuatan atau kemampuan oleh masyarakat untuk menganalisis potensi dan masalah serta mampu menemukan alternatif solusi secara mandiri. Keberdayaan dapat dilihat dari tiga aspek yaitu penentuan keputusan, kemandirian dan pemanfaatan. Pendayaan adalah memberikan daya atau empowerment kepada sasaran untuk diberi daya, kekuasaan dan peluang sesuai dengan kualitas keahlian yang telah dimiliki (Wihatnolo, RR \& Dwidjowijoto, 2007). Pendayaan DME telah diberikan kepada masyarakat dalam menjalankan usahanya yaitu produksi olahan makanan dari susu dan pemasarannya. Dilain sisi tenaga ahli biogas juga sudah berdaya dengan mampu menjalankan pengerjaan biogas sampai ke luar jawa.

\section{Impact Pemberdayaan}

Impact dari pemberdayaan masayarakat di Desa Mandiri Energi adalah adanya perubahan pola pikir, pola kerja, system usaha dan system nilai. Perubahan pola pikir dilihat dari kemampuan merubah kondisi kehidupan masyarakat untuk berperan serta dalam pengelolaan dan kegiatan Desa Mandiri Energi. Hal didorong kemauan untuk merubah kehidupan menjadi lebih baik. Sehingga kepekaan masyarakat akan potensi sekitar semakin terasah. Perubahan Pola kerja memberi dampak perubahan dalam menjalankan kegiatan yaitu perencanaan, pelaksanaan dan evaluasi kegiatan mejadi lebih efektif dan efisien. Perubahan pola kerja mampu merubah masyarakat menjadi lebih terbuka, kreatif, dan inovatif dalam berkarya (Destiningrum et al., 2018). Perubahan sistem usaha yaitu mampu melihat permintaan pasar dan peluang yang ada. Potensi pasar yang tinggi terhadap susu sapi segar membentuk perubahan system usaha dengan mulai mengembangkan usaha susu segar yang dipasarkan ke warung-warung. Kemudian pengembangan produk olahan susu yang sedang dilakukan proses ijin PIRT untuk menunjang jangkauan pemasaran yang lebih luas. Selain itu hasil dari biogas berupa pupuk mulai dijual ke petani di Karanganyar. Adanya peluang ekonomi ini setidaknya telah mampu meningkatkan pendapatan masyarakat. Perubahan system nilai yaitu tetap terjaganya kebersamaan, gotong royong dan tolong menolong diantara masyarakat. Mereka masih menjunjung norma dan adat desa.

\section{KESIMPULAN}

Proses pemberdayaan masyarakat di Desa Mundu melalui tiga tahapan. 1) penyadaran dilakukan melalui pencerahan tentang manfaat dan potensi biogas. 2) pengkapasitasan yang terdiri dari pengkapasitasan manusia dengan pelatihan manajemen ternak, pelatihan pengolahan limbah ternak, pelatihan biogas, pelatihan pembuatan pakan ternak, pelatihan pengolahan susu menjadi produk makanan olahan dan pelatihan pemandu 
wisata; pengkapasitasan organisasi dengan peningkatan kapasitas kelompok; pengkapasitasan sistem nilai dengan pengambilan keputusan bersama dalam setiap musyawarah. 3) pendayaan, yaitu memberikan wewenang kepada masyarakat dalam mengelola biogas secara mandiri.

Impact dalam pemberdayaan masyarakat yaitu terjadi perubahan pola piki yaitu adanya perubahan pengetahuan dan wawasan yang semakin maju. Perubahan pola kerja, bekerja secara efektif dan efisien. Perubahan sistem usaha yaitu memperhatikan permintaan pasar dan peluang dalam sector ekonomi. Perubahan sistem nilai yang tetap dipertahankan kebersamaan, gotong royong dan tolong menolong.

\section{DAFTAR PUSTAKA}

Aisah, I. U., \& Herdiansyah, H. 2020. Strategi Pemberdayaan Masyarakat dalam Pelaksanaan Program Desa Mandiri Energi. Share: Social Work Journal, 9(2), 130. https://doi.org/10.24198/share.v9i2.21015

Destiningrum, D., Senjawati, N. D., \& Murdiyanto, E. 2018. Pemberdayaan Masyarakat Berbasis Desa Wisata (Studi Kasus di Desa Wisata Kadisobo II, Desa Trimulyo, Kecamatan Sleman). Seminar Nasional "Inovasi Pangan Lokal Untuk Mendukung Ketahanan Pangan," April, 42-48.

Listyawati, R. N., Meidiana, C., \& Anggraeni, M. 2014. Evaluation of Energy Self-sufficient Village by Means of Emergy Indices. Procedia Environmental Sciences, 20, 30-39. https://doi.org/10.1016/j.proenv.2014.03.006

Nasdian FR. 2006. Pengembangan Masyarakat (Community Development). Departemen Komunikasi dan Pengembangan Masyarakat, Fakultas Ekologi Manusia, Institut Pertanian Bogor.

Nawawi. 2003. Metode Penelitian Bidang Sosial. Gajah Mada University Press.

Patton, M. Q. 1990. Qualitative evaluation and research methods, 2nd ed. In Qualitative evaluation and research methods, 2nd ed. Sage Publications, Inc.

Purohit, P., \& Kandpal, T. C. 2007. Techno-economics of biogas-based water pumping in India: An attempt to internalize CO2 emissions mitigation and other economic benefits. Renewable and Sustainable Energy Reviews, 11(6), 1208-1226. https://doi.org/10.1016/j.rser.2005.09.003

Purwowibowo, Kris Hendrijanto, P. A. S. 2018. Peningkatan Kapasitas Manusia Sebagai Fokus dari People Centered Development. Jurnal Aristo, 5(6).

Qadi, S. A., Sodagar, B., \& Elnokaly, A. 2018. Estimating the heating energy consumption of the residential buildings in Hebron, Palestine. Journal of Cleaner Production.

Widjajanti, K. 2011. Jurnal Ekonomi Pembangunan Model pemberdayaan masyarakat. 12.

Wihatnolo, RR \& Dwidjowijoto, R. . 2007. Manajemen Pemberdayaan, Sebuah Pengentar dan Panduan untuk Pemberdayaan Masyarakat. PT. Elex Media Komputindo Kelompok Gramedia. 